\title{
Effects of intervention with sulindac and inulin/VSL\#3 on mucosal and luminal factors in the pouch of patients with familial adenomatous polyposis
}

\author{
Pieter Friederich • Jelle Verschuur • Bjorn W. H. van Heumen • Hennie M. J. Roelofs • \\ Marloes Berkhout • Iris D. Nagtegaal • Martijn G. H. van Oijen • \\ Johannes H. J. M. van Krieken • Wilbert H. M. Peters • Fokko M. Nagengast
}

Accepted: 22 December 2010 / Published online: 18 January 2011

(C) The Author(s) 2011. This article is published with open access at Springerlink.com

\begin{abstract}
Background/aim In order to define future chemoprevention strategies for adenomas or carcinomas in the pouch of patients with familial adenomatous polyposis (FAP), a 4weeks intervention with (1) sulindac, (2) inulin/VSL\#3, and (3) sulindac/inulin/VSL\#3 was performed on 17 patients with FAP in a single center intervention study.

Primary endpoints were the risk parameters cell proliferation and glutathione S-transferase (GST) detoxification capacity in the pouch mucosa; secondary endpoints were the short chain fatty acid (SCFA) contents, $\mathrm{pH}$, and cytotoxicity of fecal water.

Methods Before the start and at the end of each 4-week intervention period, six biopsies of the pouch were taken and feces was collected during $24 \mathrm{~h}$. Cell proliferation and GST enzyme activity was assessed in the biopsies and $\mathrm{pH}$, SCFA contents, and cytotoxicity were assessed in the fecal water fraction. The three interventions (sulindac, inulin/ VSL\#3, sulindac/inulin/VSL\#3) were compared with the Mann-Whitney $U$ test.

Results Cell proliferation was lower after sulindac or VSL\#3/inulin, the combination treatment with sulindac/
\end{abstract}

P. Friederich $\cdot$ J. Verschuur $\cdot$ B. W. H. van Heumen

H. M. J. Roelofs - M. Berkhout - M. G. H. van Oijen •

W. H. M. Peters $(\bowtie) \cdot$ F. M. Nagengast

Department of Gastroenterology,

Radboud University Nijmegen Medical Centre,

P.O. Box 9101, 6500 HB Nijmegen, The Netherlands

e-mail: w.peters@mdl.umcn.nl

I. D. Nagtegaal $\cdot$ J. H. J. M. van Krieken

Department of Pathology,

Radboud University Nijmegen Medical Centre,

P.O. Box 9101, 6500 HB Nijmegen, The Netherlands
inulin/VSL\#3 showed the opposite. GST enzyme activity was increased after sulindac or VSL\#3/inulin, the combination treatment showed the opposite effect. However, no significance was reached in all these measures. Cytotoxicity, $\mathrm{pH}$, and SCFA content of fecal water showed no differences at all among the three treatment groups.

Conclusion Our study revealed non-significant decreased cell proliferation and increased detoxification capacity after treatment with sulindac or VSL\#3/inulin; however, combining both regimens did not show an additional effect.

Keywords Familial adenomatous polyposis · Sulindac . Inulin · VSL\#3 - Cell proliferation

\section{Introduction}

Familial adenomatous polyposis (FAP) is an inherited autosomal dominant disease with an estimated prevalence of $0.02 \%$. It is caused by a mutation of the APC gene and is characterized by the progressive development of hundreds to thousands of adenomatous polyps in the large intestine, in the second or third decade of life [1]. The prevalence of ileal adenomas is assumed to be $9 \%$ to $20 \%$ [2], but the occurrence of ileal carcinoma is rare. To eliminate the risk of colorectal cancer in patients with FAP, a prophylactic (procto) colectomy with an ileo-rectal anastomosis or an ileal pouch anal anastomosis (IPAA) is the treatment of choice [3].

Despite of resecting all colonic mucosa, adenomas occur in the pouch with a reported incidence of $35 \%$ to $75 \%$ after a follow-up of at least 5 years [4-9]. If the adenomacarcinoma sequence in the pouch is the same as in the colon, which takes approximately 20 years, a rise in pouch carcinomas could well be expected in the near future. So 
far, a limited number of patients with a pouch carcinoma has been described [9-14].

After an IPAA procedure, colonic metaplasia of the ileal mucosa of the pouch occurs in the form of villous atrophy, crypt hyperplasia, and an increased excretion of mucin [15-17].

In the pouch, there is also an increase in anaerobic bacteria [18, 19], leading to more deconjugation and dehydroxylation of bile acids [19], whereas an increase in short chain fatty acids (SCFA) to colonic levels is also observed [20]. Such changes may influence the balance between cell proliferation and apoptosis, which is disturbed in colorectal cancer [21]. We recently showed that after construction of an IPAA, cell proliferation in the ileal pouch was increased as compared to the levels of the afferent ileal loop [22].

The effect of intraluminal components on apoptosis, cell proliferation, and differentiation is complex. Depending on the models used, SCFA like butyrate can enhance or decrease mucosal proliferation [23-25]. Butyrate can also induce apoptosis, which is strongly down-regulated in FAP $[26,27]$. Secondary de-conjugated bile acids like deoxycholate and chenodeoxycholate may stimulate cell proliferation [28], apoptosis [29], and cyclooxygenase-2 [30] (COX-2), which is strongly over-expressed in colorectal cancer [31]. Thus, luminal components may be responsible for alterations in mucosal cell kinetics, and measurement of the cytotoxicity of the fecal water could indicate the presence of damaging constituents in the pouch [32].

Mucosal factors may also contribute to the adenoma and carcinoma risk. Mucosal protective systems such as the glutathione S-transferases (GSTs) are expressed along the human intestine, with much higher levels in the ileum than in the colon [33]. GSTs are a class of enzymes that are pivotal in the detoxification of carcinogens. An inverse correlation between the GST enzyme activity in the mucosa of the gastrointestinal tract and the tumor incidence has been demonstrated [34]. The GST enzyme activity is downregulated during colonic metaplasia in the pouch of patients with FAP [35], which is in line with the much lower GST enzyme contents generally found in colon as compared to small intestinal tissue $[33,36]$.

Non steroidal anti-inflammatory drugs (NSAIDs) are potential agents for the chemoprevention of colorectal cancer. They inhibit both COX-1 and COX-2, which are enzymes involved in prostaglandin synthesis. There is strong evidence that COX-2 expression is associated with colorectal cancer [37]. In patients with FAP, COX-2 expression is also elevated [38]. Chemoprevention trials with NSAIDs have shown both a reduction in number and size of colorectal adenomas in patients with FAP [39, 40]. Sulindac has been approved by the Food and Drug
Administration as an adjunct in the treatment of FAP. Although the chemoprevention by NSAIDs is promising, the adenoma regression is only partly and temporarily, whereas adenomas with low COX-2 expression may be resistant to NSAIDs [41].

Therefore, it would be worthwhile to combine NSAIDs with other chemopreventive agents such as pre- or probiotics. These so called "nutriceuticals" may induce a flora which is capable of decreasing bile acid concentrations, enhancing formation of SCFA such as butyrate and reducing intestinal $\mathrm{pH}$ [42]. Butyrate is able to cause apoptosis and to protect against carcinogens by enhancing expression of mucosal detoxification enzymes such as glutathione S-transferases [43]. Lactic acid-producing bacteria such as Bifido bacteria or Lactobacilli are the most widely studied probiotics with potential cancer protective effects, whereas intestinal exposure to pre/probiotics can occur via oral intake $[44,45]$. VSL\#3, a mixture of four Lactobacilli, three Bifidum, and one Streptococcus species, has shown beneficial effects on pouchitis in patients with ulcerative colitis (UC) [46, 47]. In vivo studies with VSL\#3 in rats showed a decrease of colonic cell proliferation [48]. Moreover, inulin can inhibit cell proliferation and induce apoptosis in vitro [49], both features which are disturbed in FAP. We earlier demonstrated that bacterial fermentation of orally ingested fructooligosaccharides, a type of inulin, or resistant starch, occurs in patients with an IPAA [50].

The purpose of this intervention study is to investigate whether short-term modulation of luminal or mucosal factors in the pouch of patients with FAP is possible by NSAID (sulindac) monotherapy, combination of pre- and probiotics (inulin/VSL\#3), and the combination of both these intervention regimens (sulindac/inulin/VSL\#3).

\section{Material and methods}

\section{Patients and interventions}

Patients with FAP and an IPAA, who were under surveillance at the Department of Gastroenterology of the Radboud University Nijmegen Medical Centre or regional affiliated hospitals, were invited to participate in this study. Seventeen patients with FAP were included in the period May 2006-July 2006. The diagnosis FAP was based on either a clinical presentation of at least 100 colonic adenomas or presence of a mutation in the APC gene.

A randomized pilot study with sulindac monotherapy (300 mg/day; 1 tablet of $100 \mathrm{mg}$ in the morning and two tablets in the evening), combination therapy with VSL\#3 $\left(9 \times 10^{11}\right.$ bacteria/day) and inulin $(12 \mathrm{~g} / \mathrm{day})$, or the combination of sulindac and VSL\#3/inulin was performed 
according to the scheme presented in Fig. 1. VSL\#3 was provided by Sigma-Tau BV, Utrecht, the Netherlands. VSL\#3 was mixed with some yoghurt and taken in the evening. VSL\#3 contains Streptococcus thermophilus, three strains of Bifidobacteria (Bifidobacterium breve, Bifidobacterium longum, Bifidobacterium infantis) and four strains of Lactobacilli (Lactobacillus acidophilus, Lactobacillus plantarum, Lactobacillus casei, and Lactobacillus bulgaricus). Inulin (Frutafit ${ }^{\circledR}$ IQ) was provided by Sensus, Roosendaal, the Netherlands, and it was taken two times a day in sachets of $6 \mathrm{~g}$ each. Study participants were instructed to consume their normal home diet during the course of the study.

Inclusion criteria: male and female patients between 18 and 70 years of age and diagnosed with familial adenomatous polyposis, with an ileal pouch anal anastomosis (IPAA). Exclusion criteria were: known allergy to the study medication, prior gastric or intestinal ulcer, history or other evidence of severe illness, malignancy or any other condition which makes the patient unsuitable for the study, women with ongoing pregnancy or breast feeding, chronic liver disease or chronic renal disease, serum creatinin level $>1.5$ times the upper limit of normal, history of severe allergy, history of symptomatic and/or significant cardiovascular disease.

The study was approved by the regional (Arnhem/ Nijmegen) medical ethical review committee (CMO no. 2002/111), and informed consent was obtained from all patients.

\section{Luminal factors}

Feces was collected on dry ice in separate portions during $24 \mathrm{~h}$, on the day before endoscopy. It was transported to the laboratory on dry ice and was subsequently stored at $-20^{\circ} \mathrm{C}$ until processing. The thawed portions of feces were weighed, added together, and homogenized with a blender. Next, the $\mathrm{pH}$ of the feces was measured at room temperature (pH meter PHM 82, Radiometer, Copenhagen, Denmark). Fecal water was prepared by centrifugation of a portion of the homogenized feces at $150,000 \times g$ for $1 \mathrm{~h}$ at $4^{\circ} \mathrm{C}$. Fecal water was filtered through a $0.20-\mu \mathrm{m}$ filter (Schleicher \& Schuell, Dassel, Germany), and it was stored in small portions at $-20^{\circ} \mathrm{C}$ until further analysis.

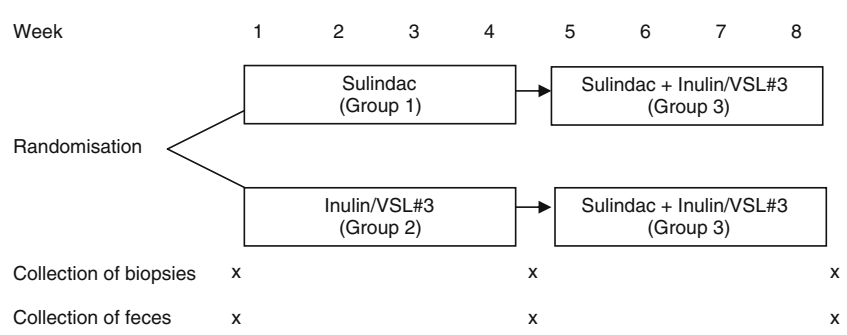

Fig. 1 Study design
Short chain fatty acids in fecal water fractions were determined as described before [50].

Cytotoxicity of the fecal water was measured as described before [32], with slight modifications. In short, HT29 cells were seeded at a density of 15,000 cells/well in flat-bottomed 96 wells plates (Costar, Corning Incorporated, Corning, NY, USA). The HT29 cells were allowed to grow for $24 \mathrm{~h}$ in PC-1 culture medium (Lonza, Verviers, Belgium), culture medium was removed, and the cells were incubated with $200 \mu \mathrm{l}$ test sample and controls. PC-1 medium alone was used as a negative control and PC-1 medium containing $3.2 \mathrm{mM}$ unconjugated deoxycholic acid (Sigma, St Louis, USA) was used as a positive control for cytotoxicity. Wells without cells served as background correction in the measurements. Fecal water diluted in PC-1 medium was added to the wells in the following dilutions: 2,4 , 8, etc., until 1,024 times. Every dilution was measured in octuple. After incubating for $24 \mathrm{~h}$, the medium was removed and new PC-1 medium containing $10 \%(v / v)$ proliferation reagent WST-1 (Roche, Penzberg, Germany) was added to each well. In viable cells, WST-1 will be converted to formazan by mitochondrial activity. After $2 \mathrm{~h}$, the color intensity of the formazan formed was quantified in a microplate reader (Thermomax, Molecular Devices, Sopachem B.V., Wageningen, the Netherlands). The absorbance was measured against the background controls at a wavelength of $405 \mathrm{~nm}$ and a reference wavelength of $620 \mathrm{~nm}$. The cell viability was expressed as the percentage of absorption of test samples, as compared with that of wells incubated with medium alone. Results are expressed as the dilution factors of the fecal water at which $50 \%$ of the cells do survive. The mean value of three independent experiments for each sample is given.

\section{Mucosal factors}

Before endoscopy, patients were fasted overnight. On the day of examination, patients were encouraged to drink liberally. No laxatives or cathartic enemas were given. To clear the pouch of fecal ruminants, two $250 \mathrm{ml}$ water enemas were given prior to endoscopy.

Six biopsies were taken at random locations from the pouch mucosa, at least $5 \mathrm{~cm}$ proximal from the anal verge. Two biopsies were stretched on filter paper to maintain a correct orientation of crypts, biopsies were subsequently fixated in formalin and embedded in paraffin. Four biopsies were frozen in liquid nitrogen and stored at $-80^{\circ} \mathrm{C}$ until use.

Cell proliferation was measured by immunohistochemistry in the stretched formalin-fixated biopsies exactly as described by us before [22]. The cell proliferation activity was assessed after staining with the monoclonal antibody MIB-1 (Dako A/ S, Glostrup, Denmark), which recognizes the Ki-67 nuclear antigen. Evaluation of immunostaining results was done 
while the investigators were blinded for the treatment of the patient. For evaluation of MIB-1 immunostained tissue sections, crypts whose entire length could be visualized were photographed under $400 \times$ magnification using a Zeiss KS400 computer-aided system. Crypts were excluded if they did not reach the muscularis mucosae or had multilayered bases. MIB-1 positivity was identified as brown nuclear staining. The number of MIB-1 positive epithelial cells and the total number of epithelial cells in up to five crypts per tissue section were counted from the screen. The labeling index for each crypt was given by the ratio of MIB-1 positive cells over the total number of crypt epithelial cells. For each patient, the labeling index was expressed as means of three to five counted crypts. If less than three crypts could be evaluated, the patient was excluded from analysis.

Four biopsies were thawed, pooled, homogenized, and glutathione S-transferase enzyme activity with 1-chloro,2,4dinitrobenzene as substrate was assayed as described before [33].

\section{Statistical analyses}

Statistical analyses were performed with SPSS statistical software, version 16.0 (SPSS Inc, Chicago, Illinois, USA). Frequency tables were provided describing patient baseline characteristics. Pearson's chi-squared test was used to compare categorical variables. Fisher's exact test was used where appropriate. Continuous variables were compared with Mann-Whitney $U$ test.

Outcomes data were then pooled, and the difference between post- and pre-intervention was plotted (using Prism Graphpad) and compared between three interventions using Mann-Whitney $U$ analyses. A two-sided $p$ value of $<0.05$ was considered statistically significant.

\section{Results}

Seventeen patients with FAP, all having an IPAA (median age of the pouch 13, range 1-21 years), started the study protocol (Fig. 1). Some baseline characteristics of these patients are given in Table 1.

One patient, who started with sulindac monotherapy, developed an antral bleeding after 2 days of sulindac use and stopped medication. This patient agreed to continue the study 4 weeks later, than receiving VSL\#3/inulin for 4 weeks, a regimen that was finished without further complications. Two patients did not finish one intervention period for reasons not associated with side effects: one patient who started with VSL\#3/inulin, stopped during the second regimen (combination of sulindac/VSL\#3/inulin), whereas another patient did not complete the first VSL\#3/ inulin regimen, but did successfully complete the combination regimen. Summarizing, seven patients successfully completed the intervention with sulindac monotherapy, nine patients completed the intervention with VSL\#3/inulin, and 15 patients completed the intervention with the combination of sulindac/VSL\#3/inulin (see Table 1).

Primary endpoints were cell proliferation and GST enzyme activity (mucosal factors), secondary endpoints were short chain fatty acid (SCFA) contents, $\mathrm{pH}$, and cytotoxicity of the fecal water (luminal factors). The primary data of these primary and secondary endpoints, as measured in biopsies and feces of the patients, are given in Table 2. The cell proliferation rates before and after the intervention period were compared within each patient, and the differences in cell proliferation, post-intervention minus pre-intervention values, are given in Fig. 2. Although median cell proliferation values are down-regulated in the sulindac and VSL\#3/inulin groups, this was not seen in the combination group. Overall, no significant differences were observed $(P=0.13)$.

For GST enzyme activity (Fig. 3), a similar pattern was observed: median GST enzyme activities are up-regulated in the sulindac and VSL\#3/inulin groups but not in the combination group. Overall, no significant differences were observed $(P=0.16)$.

For the secondary endpoints, cytotoxicity, $\mathrm{pH}$, and concentrations of SCFA in the fecal water (see Figs. 4, 5, and 6) no significant differences were also observed in the post-treatment vs. pre-treatment values $(P$ values of 0.19 , 0.64 , and 0.98 for cytotoxicity, $\mathrm{pH}$, and concentrations of SCFA, respectively).

\section{Discussion}

Although both the pouch and its afferent loop contain the same pre-existing ileal mucosa, adenomas occur more

Table 1 Patient characteristics

\begin{tabular}{llll}
\hline Variable & Group 1 (sulindac) & Group 2 (VSL\#3/inulin) & Group 3 (sulindac+VSL\#3/inulin) \\
\hline Number & 7 & 9 & 15 \\
Males/females & $4 / 3$ & $6 / 3$ & $10 / 5$ \\
Median age (range) in years & $36(19-63)$ & $38(18-53)$ & $38(18-63)$ \\
Median age pouch (range) in years & $10(3-21)$ & $16(1-21)$ & $13(1-21)$ \\
\hline
\end{tabular}


Table 2 Median (range) values of the endpoint parameters

\begin{tabular}{llccc}
\hline Endpoint parameter & Baseline & Group 1 (sulindac) & Group 2 (VSL\#3+inulin) & Group 3 (sulindac+VSL\#3+inulin) \\
\hline Proliferation $^{\mathrm{a}}$ & $0.51(0.35-0.80)$ & $0.47(0.15-0.65)$ & $0.42(0.39-0.55)$ & $0.60(0.39-0.75)$ \\
GST $^{\mathrm{a}}$ & $376(271-606)$ & $421(334-523)$ & $382(328-563)$ & $399(229-518)$ \\
Cytotoxicity $^{\mathrm{a}}$ & $54.2(11.7-325)$ & $95.0(20.8-150)$ & $50.8(1.5-237)$ & $95.0(20.0-177)$ \\
SCFA $^{\mathrm{a}}$ & $77.2(42.1-118)$ & $71.9(51.4-121)$ & $67.8(31.2-138)$ & $77.8(42.1-102)$ \\
Fecal pH $^{\mathrm{a}}$ & $5.92(4.90-7.37)$ & $5.48(4.82-7.22)$ & $6.05(4.82-6.96)$ & $5.53(4.86-6.59)$ \\
\hline
\end{tabular}

Proliferation is given as the ratio labeled/unlabeled cells. GST activity is given in nanomoles per minute milligram protein. Cytotoxicity is the dilution factor at which $50 \%$ of the cells have died. SCFA is given in millimoles per liter. Fecal pH is given in pH units

${ }^{a}$ Values are given as median (range)

frequently in the pouch of patients with FAP, suggesting an accelerated adenoma formation in the pouch [5-8]. Previously, we demonstrated in patients with FAP that cell proliferation was significantly higher in the pouch mucosa than in the mucosa of the afferent ileal loop, which could partly explain the higher adenoma and carcinoma rates in the pouch [22]. Several studies indicated that cell proliferation of normal-appearing colorectal mucosa of patients with adenomas or carcinomas was $19 \%$ to $86 \%$ higher compared to colorectal mucosa of healthy persons [51, 52]. These findings strongly suggest an association between the presence of adenomas or carcinomas and an increased mucosal cell proliferation. In addition, intestinal epithelial cell proliferation in patients with FAP is very high $[53,54]$ which stresses the need for studies on lowering the cell proliferation in these patients. Intraluminal changes that occur after construction of the pouch, such as changes in bacterial flora, bile acid composition, concentration of SCFA, pH, etc., can explain the higher cell proliferation in the pouch mucosa in comparison to mucosa of the afferent ileal loop. Therefore, in this study, we focused to improve

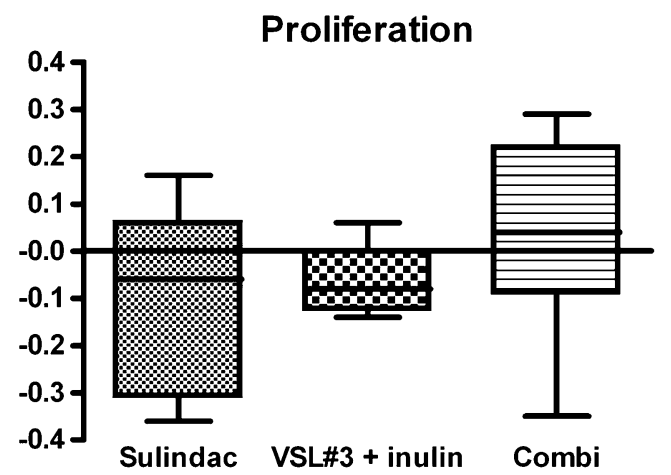

Fig. 2 For each patient, the difference in cell proliferation at the end of the intervention period, minus cell proliferation at start, was calculated. Median differences (solid line in each bar) in cell proliferation are given for each intervention group. Bars represent $25 \%$ and $75 \%$ percentiles, and the minimum and maximum differences are also indicated ( $T$ bar). Number of patients involved are: sulindac, $n=7$, VSL\#3+inulin, $n=9$, sulindac + VSL\#3+inulin (combi), $n=14, P$ value (Kruskal-Wallis) $=0.13$ short time risk parameters both from mucosal (cell proliferation, mucosal GST defense against toxins/carcinogens) as well as luminal (cytotoxicity, $\mathrm{pH}$, and concentrations of SCFA) origin. We did choose for a short intervention period of 4 weeks, since we focused on the mucosa of the human intestine, which is renewed every 3-4 days [55] and on some luminal factors present in the fecal water, which may have even shorter half-lives.

Since sulindac has been proved effective in reducing the number and size of colon adenomas in patients with FAP [39], in short time experiments, we expected a reduction of cell proliferation as an important factor in the formation of adenomas or carcinomas. Median cell proliferation rates are somewhat reduced; however, no significance is reached in the sulindac and VSL\#3/inulin groups. This tendency, however, is not seen in the combination group (sulindac + VSL\#3+inulin). Exactly the same favorable tendency is seen for the GST detoxification activity in the pouch mucosa: after treatment with sulindac or VSL\#3/inulin, there is an increase in median GST activity, which is not further elevated in the combination group. Again, however, results did not reach statistical significance. With respect to

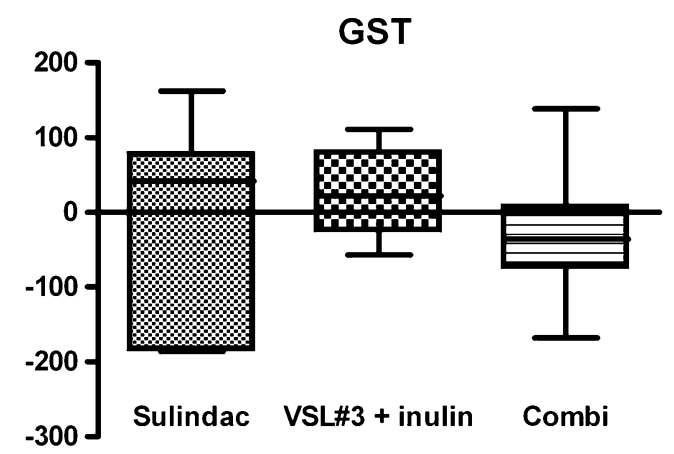

Fig. 3 For each patient, the difference in GST enzyme activity at the end of the intervention period, minus GST enzyme activity at start, was calculated. Median differences (solid line in each bar) in GST enzyme activity are given for each intervention group. Bars represent $25 \%$ and $75 \%$ percentiles, and the minimum and maximum differences are also indicated ( $T$ bar). Number of patients involved are: sulindac, $n=7$, VSL\#3+inulin, $n=9$, sulindac +VSL\#3+inulin (combi), $n=15, P$ value (Kruskal-Wallis) $=0.16$ 


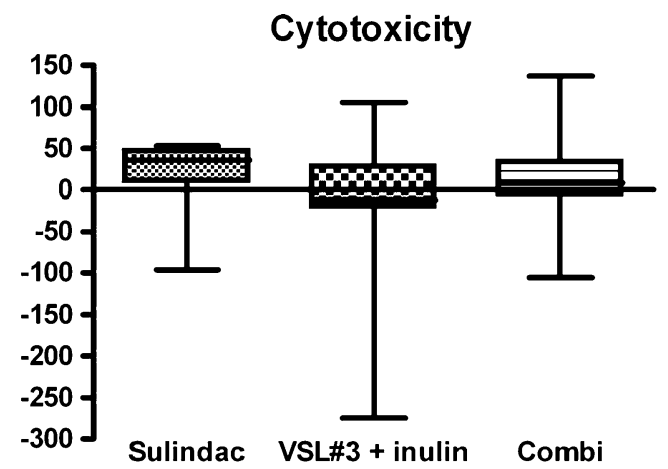

Fig. 4 For each patient, the difference in cytotoxicity of fecal water at the end of the intervention period, minus cytotoxicity at start, was calculated. Median differences (solid line in each bar) in cytotoxicity are given for each intervention group. Bars represent $25 \%$ and $75 \%$ percentiles, and the minimum and maximum differences are also indicated ( $T$ bar). Number of patients involved are: sulindac, $n=7$, VSL\#3+inulin, $n=9$, sulindac+VSL\#3+inulin (combi), $n=15$, $P$ value $($ Kruskal - Wallis $)=0.19$

the primary endpoints cell proliferation and GST enzyme activity, we can conclude that there may be a positive effect (lowering of cell proliferation and increase of GST enzyme activity) of sulindac monotherapy and treatment with VSL\#3/inulin, but surprisingly, when both regimens are combined, no additive effect is achieved. Based on these results, we can elaborate on the suspected number of patients that need to be included. For example, using the mean GST activity in the sulindac monotherapy group versus the VSL\#3/inulin group, a sample size of 67 patients with FAP in each group is needed to detect a probability of 0.64 that an observation in the sulindac group is less than in the VSL\#3/inulin group, using a Mann-Whitney $U$ test with a 0.05 two-sided significance level and $80 \%$ power.

For the luminal parameters measured in this study, the results more clearly indicate that no effect on fecal $\mathrm{pH}$,

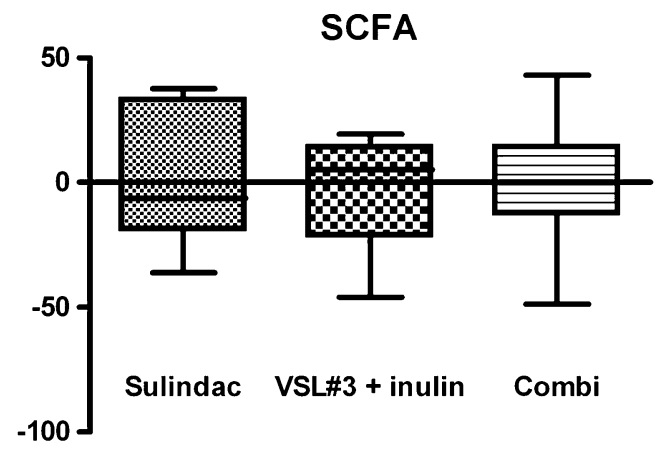

Fig. 5 For each patient, the difference in total SCFA concentrations in fecal water at the end of the intervention period, minus total SCFA concentrations at start, was calculated. Median differences (solid line in each bar) in total SCFA concentrations in fecal water are given for each intervention group. Bars represent $25 \%$ and $75 \%$ percentiles, and the minimum and maximum differences are also indicated ( $T$ bar). Number of patients involved are: sulindac, $n=7$, VSL $\# 3+$ inulin, $n=9$, sulindac + VSL\#3+inulin (combi), $n=15, P$ value (Kruskal-Wallis) $=0.98$
SCFA content in fecal water, and to a lesser extent on the cytotoxicity has to be expected from any intervention regimen applied in this study. From sulindac monotherapy, hardly any effect on SCFA and $\mathrm{pH}$ was expected. However, the VSL\#3/inulin arm was included to provoke an effect on both these parameters, since inulin, with the help of the eight different strains of Lactobacilli and Bifidobacteria in VSL\#3, was expected to be degraded into SCFA in the pouch [50], which subsequently could have a lowering effect on the $\mathrm{pH}$. Our data, however, seem to indicate that absolutely no effect on $\mathrm{pH}$ and SCFA can be expected even after scaling up the study. This is in contrast with the results of Welters et al. [56] who clearly demonstrated fermentation of inulin in the pouch of patients with ulcerative colitis. This might be explained either by the difference in dose of inulin ( 24 vs. $12 \mathrm{~g}$ daily in our study) or by the different characteristics of pouches in patients with FAP as compared to patients with UC. Duffy et al. [57] found differences in bacterial colonization in pouches of patients with UC and FAP and they speculated that pouch inflammation, which is frequently seen in UC, might be associated to this finding. Furthermore, inhibition of inulin fermentation by VSL\#3 seems highly unlikely since inulin is bifidogenic [58] and Bifidobacteria are a main component of VSL\#3.

To our knowledge, this is the first intervention study on patients with FAP having an IPAA, which is a strength of this study. Moreover, since APC mutations are main contributing events in colorectal carcinogenesis in general, studies performed in patients with FAP, where colon carcinogenesis is highly accelerated, might provide insight in (chemo) prevention of sporadic colorectal cancer. However, since FAP is a rare disorder, it is difficult to study in a single center fashion, even in our center which is specialized in hereditary colorectal cancer. The main

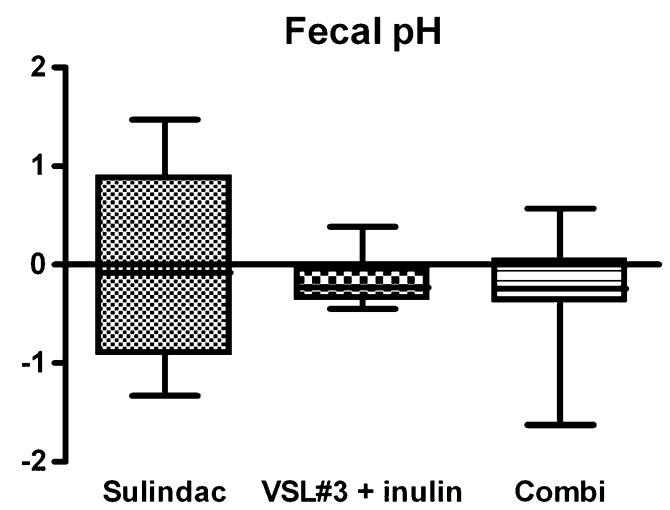

Fig. 6 For each patient, the difference in fecal $\mathrm{pH}$ at the end of the intervention period, minus fecal $\mathrm{pH}$ at start, was calculated. Median differences (solid line in each bar) in fecal $\mathrm{pH}$ are given for each intervention group. Bars represent $25 \%$ and $75 \%$ percentiles, and the minimum and maximum differences are also indicated (T bar). Number of patients involved are: sulindac, $n=7$, VSL $\# 3+$ inulin, $n=9$, sulindac + VSL $\# 3+$ inulin (combi), $n=15, P$ value (Kruskal-Wallis) $=0.64$ 
weakness of this study therefore is the small number of patients included in the study.

In conclusion, in addition to the advantageous effect on adenomas as reported before for sulindac, we investigated whether additional or additive positive effects could be achieved on some risk parameters by trying to modulate both mucosal and luminal factors. However, we did not find an indication that the combination of VSL\#3/inulin/sulindac could add anything for the chemoprevention of adenomas in patients with FAP, in comparison with sulindac alone.

Acknowledgements This work was supported by a grant (KUN 2003-2911) from the Dutch Cancer Society KWF.

The authors want to thank Dr. Albert Tangerman for analyses of the short chain fatty acids and Dr. Diederick Meyer for providing the inulin.

Open Access This article is distributed under the terms of the Creative Commons Attribution Noncommercial License which permits any noncommercial use, distribution, and reproduction in any medium, provided the original author(s) and source are credited.

\section{References}

1. Bulow S, Alm T, Fausa O, Hultcrantz R, Jarvinen H, Vasen $H$ (1995) Duodenal adenomatosis in familial adenomatous polyposis: DAF profect group. Int J Colorectal Dis 10:43-46

2. Tonelli F, Nardi F, Bechi P, Taddei G, Gozzo P, Romagnoli P (1985) Extracolonic polyps in familial polyposis coli and Gardner's syndrome. Dis Colon Rectum 28:664-668

3. Vasen HFA, van Duijvendijk P, Buskens E, Bulow C, Bjork J, Jarvinen HJ, Bulow S (2001) Decision analysis in the surgical treatment of patients with familial adenomatous polyposis: a Dutch-Scandinavian collaborative study including 659 patients. Gut 49:231-235

4. Nugent KP, Spigelman AD, Nicholls RJ, Talbot IC, Neale K, Phillips RK (1993) Pouch adenomas in patients with familial adenomatous polyposis. Br J Surg 80:1620

5. Iida $M$, Itoh $H$, Matsui $T$, Mibu R, Iwashita A, Fujishima $M$ (1989) Ileal adenomas in proctocolectomy patients with familial adenomatosis coli/Gardner's syndrome. Incidence and endoscopic appearance. Dis Colon Rectum 32:1034-1038

6. Wu SJ, McGannon EA, Church JM (1998) Incidence of neoplastic polyps in the ileal pouch of patients with adenomatous polyposis after restorative proctocolectomy. Dis Colon Rectum 41:552-557

7. Parc YR, Olschwang S, Desaint B, Schmitt G, Parc RG, Tiret E (2001) Familial adenomatous polyposis: prevalence of adenomas in the ileal pouch after restorative colectomy. Ann Surg 233:360-364

8. Thompson-Fawcett MW, Marcus VA, Redston M, Cohen Z, McLeod RS (2001) Adenomatous polyps develop commonly in the ileal pouch of patients with familial adenomatous polyposis. Dic Colon Rectum 44:347-353

9. Friederich P, de Jong AE, Mathus-Vliegen LM, Dekker E, van Krieken JH, Dees J, Nagengast FM, Vasen HFA (2008) Risk of developing adenomas and carcinomas in the ileal pouch in patients with familial adenomatous polyposis. Clin Gastroenterol Hepatol 6:1237-1242

10. Hoehner JC, Metcalf AM (1994) Development of invasive adenocarcinoma following colectomy with ileoanal ansatomosis for familial polyposis coli. Dis Colon Rectum 37:824-828
11. Von Herbay A, Stern J, Herfarth C (1996) Pouch-anal cancer after restorative proctocolectomy for familial adenomatous polyposis. Am J Surg Pathol 20:995-999

12. Bassuini MMA, Billings PJ (1996) Carcinoma in an ileal pouch after restorative proctocolectomy for familial adenomatous polyposis. Br J Surg 85:506

13. Palkar VM, deSouza LJ, Jagannath P, Naresh KN (1997) Adenocarcinoma arising in "J" pouch after total proctocolectomy for familial polyposis coli. Indian J Cancer 34:16-19

14. Vuilleumier H, Halkic N, Ksontini R, Gillet M (2000) Columnar cuff cancer after restorative proctocolectomy for famlilial adenomatous polyposis. Gut 47:732-734

15. Shepherd NA, Jass JR, Duval I, Moskowitz RL, Nicholls RJ, Morson CB (1987) Restorative proctocolectomy with ileal reservoir; pathological and histochemical study of mucosal biopsy specimens. J Clin Pathol 40:601-607

16. Corfield AP, Warren BF, Bartolo DC, Wagner SA, Clamp JR (1992) Mucin changes in ileoanal pouches monitored by metabolic labeling and histochemistry. Br J Surg 79:1209-1212

17. De Silva HJ, Miljard PR, Kettlewell M, Mortensen NJ, Prince C, Jewell DP (1991) Mucosal characteristics of pelvic ileal pouches. Gut 32:61-65

18. Nasmyth DG, Godwin PG, Dixon MF, Williams NS, Johnston D (1989) Ileal ecology after pouch-anal anastomosis or ileostomy. A study of mucosal morphology, fecal bacteriology, fecal volatile fatty acids, and their interrelationship. Gastroenterology 96:817824

19. Natori H, Utsonomiya J, Yamamura T, Benno Y, Uchida K (1992) Fecal and stomal bile acid composition after ileostomy or ileoanal anstomosis in patients with chronic ulcerative colitis and adenomatosis coli. Gastroenterology 102:1278-1288

20. Clausen MR, Tvede M, Mortensen PB (1992) Short-chain fatty acids in pouch contents from patients with and without pouchitis after ileal pouch-anal anastomosis. Gastroenterology 103:1144-1153

21. Chung DC (2000) The genetic basis of colorectal cancer: insights into critical pathways of tumorigenesis. Gastroenterology 119:854-865

22. Friederich $\mathrm{P}$, van Heumen BWH, Nagtegaal ID, Berkhout M, van Krieken JHJM, Peters WHM, Nagengast FM (2007) Increased epithelial cell proliferation in the ileal pouch mucosa of patients with familial adenomatous polyposis. Virchows Arch 451:659-667

23. Kripke SA, Fox AD, Berman JM, Settle RG, Rombeau JL (1989) Stimulation of intestinal mucosal growth with intracolonic infusion of short-chain fatty acids. J Parenter Enteral Nutr 13:109-116

24. Scheppach W, Sommer H, Kirchner T, Paganelli GM, Bartram P, Christl S, Richter F, Dusel G, Kasper H (1992) Effect of butyrate enemas on the colonic mucosa in distal ulcerative colitis. Gastroenterology 103:51-56

25. Velazquez OC, Zhou D, Seto RW, Jabbar A, Choi J, Lederer HM, Rombeau JL (1996) In vivo crypt surface hyperproliferation is decreased by butyrate and increased by deoxycholate in normal rat colon: associated in vivo effects on c-Fos and c-Jun expression. J Parenter Enteral Nutr 20:243-250

26. Hague A, Manning AM, Hanlon KA, Huschtscha LI, Hart D, Paraskeva C (1993) Sodium butyrate induces apoptosis in human colonic tumour cell lines in a p53-independent pathway: implications for the possible role of dietary fibre in the prevention of large-bowel cancer. Int J Cancer 55:488-505

27. Heerdt BG, Houston MA, Augenlicht LH (1994) Potentiation by specific short-chain fatty acids of differentiation and apoptosis in human colonic carcinoma cell lines. Cancer Res 54:3288-3293

28. McMillan L, Butcher S, Wallis Y, Neoptolemos JP, Lord JM (2000) Bile acids reduce the apoptosis-inducing effect of sodium butyrate on human colon adenoma $(\mathrm{AA} / \mathrm{C} 1)$ cells: implications for colon carcinogenesis. Biochem Biophys Res Commun 273:45-49 
29. Powell AA, LaRue JM, Batta AK, Martinez JD (2001) Bile acid hydrophobicity is correlated with induction of apoptosis and/or growth arrest in HCT116 cells. Biochem J 356:481-486

30. Glinghammar B, Rafter J (2001) Colonic luminal contents induce cyclooxygenase 2 transcription in human colon carcinoma cells. Gastroenterology 120:401-410

31. Eberhart CE, Coffey RJ, Radhika A, Giardiello FM, Ferrenbach S, DuBois RN (1994) Up-regulation of cyclooxygenase 2 gene expression in human colorectal adenomas and adenocarcinomas. Gastroenterology 107:1183-1188

32. van Munster IP, Tangerman A, de Haan AF, Nagengast FM (1993) A new method for the determination of the cytotoxicity of bile acids and aqueous phase of stool: the effect of calcium. Eur J Clin Investig 23:773-777

33. Peters WHM, Kock L, Nagengast FM, Kremers PG (1991) Biotransformation enzymes in human intestine: critical low levels in the colon? Gut 32:408-412

34. Peters WHM, Roelofs HMJ, Hectors MP, Nagengast FM, Jansen JBMJ (1993) Glutathione and glutathione S-transferases in Barrett's epithelium. Br J Cancer 67:1413-1417

35. Friederich $P$, Berkhout $M$, Roelofs $H M J$, van Goor $H$, van Krieken JHJM, Peters WHM, Nagengast FM (2006) Decreased levels of mucosal detoxification enzymes in the pouch of patients with familial adenomatous polyposis. Br J Surg 93:1108-1114

36. Coles BF, Chen G, Kadlubar FF, Radominska-Pandya A (2002) Interindividual variation and organ-specific patterns of glutathione S-transferase alpha, mu, and pi expression in gastrointestinal tract mucosa of normal individuals. Arch Biochem Biophys 403:270-276

37. Fujita T, Matsui M, Takaku K, Uetake H, Ichikawa W, Taketo MM, Sugihara K (1998) Size- and invasion-dependent increase in cyclooxygenase 2 levels in human colorectal carcinomas. Cancer Res 58:4823-4826

38. Khan KN, Masferrer JL, Woerner BM, Soslow R, Koki AT (2001) Enhanced cyclooxygenase-2 expression in sporadic and familial adenomatous polyposis of the human colon. Scand J Gastroenterol $36: 865-869$

39. Giardiello FM, Hamilton SR, Krush AJ, Piantadosi S, Hylind LM, Celano P, Booker SV, Robinson CR, Offerhaus GJ (1993) Treatment of colonic and rectal adenomas with sulindac in familial adenomatous polyposis. N Engl J Med 328:1313-1316

40. Steinbach G, Lynch PM, Phillips RK, Wallace MH, Hawk E, Gordon GB, Wakabayashi N, Saunders B, Shen Y, Fujimura T, Su LK, Levin B (2000) The effect of celecoxib, a cyclooxygenase-2 inhibitor, in familial adenomatous polyposis. N Engl J Med 342:1946-1952

41. Keller JJ, Offerhaus GJ, Drillenburg P, Caspers E, Musler A, Ristimaki A, Giardiello FM (2001) Molecular analysis of sulindac-resistant adenomas in familial adenomatous polyposis. Clin Cancer Res 7:4000-4007

42. Lidbeck A, Geltner-Allinger U, Orrhage KM, Ottava L, Brismar B, Gustafsson JA, Rafter JA, Nord CE (1991) Impact of lactobacillus acidophilus supplements on the faecal microflora and soluble faecal bile acids in colon cancer patients. Microb Ecol Health Dis 4:81-88

43. Pool-Zobel BL, Sauer J (2007) Overview of experimental data on reduction of colorectal cancer risk by inulin-type fructans. J Nutr 137:2580S-2584S

44. Lidbeck A, Overvik E, Rafter J, Nord CE, Gustafsson JA (1992) Effect of Lactobacillus acidophilus supplements on mutagen excretion in feces and urine in humans. Microb Ecol Health Dis 5:59-67

45. Gibson GR, Probert HM, Loo JV, Rastall RA, Roberfroid MB (2004) Dietary modulation of the human colonic microbiota: updating the concept of prebiotics. Nutr Res Rev 17:259-275

46. Gionchetti P, Rizzello F, Morselli C, Poggioli G, Tambasco R, Calabrese C, Brigidi P, Vitali B, Straforini G, Campieri M (2007) High-dose probiotics for the treatment of active pouchitis. Dis Colon Rectum 50:2075-2082

47. Shen B, Brzezinski A, Fazio VW, Remzi FH, Achkar JP, Bennett AE, Sherman K, Lashner BA (2005) Maintenance therapy with a probiotic in antibiotic-dependent pouchitis: experience in clinical practice. Aliment Pharmacol Ther 22:721-728

48. Linsalata M, Russo F, Berloco P, Valentini AM, Caruso ML, De Simone C, Barone M, Polimeno L, Di Leo A (2005) Effects of probiotic bacteria (VSL\#3) on the polyamine biosynthesis and cell proliferation of normal colonic mucosa of rats. In Vivo 19:989995

49. Munjal U, Glei M, Pool-Zobel BL, Scharlau D (2009) Fermentation products of inulin-type fructans reduce proliferation and induce apoptosis in human colon tumour cells of different stages of carcinogenesis. Br J Nutr 102:663-671

50. Alles MS, Katan MB, Salemans JM, Van Laere KM, Gerichhausen MJ, Rozendaal MJ, Nagengast FM (1997) Bacterial fermentation of fructooligosaccharides and resistant starch in patients with an ileal pouch-anal anastomosis. Am J Clin Nutr 66:1286-1292

51. PonzdeLeon M, Roncucci L, Di Donato P, Tassi L, Smerieri O, Amorico MG, Malagoli G, De Maria D, Antonioli A, Chahin NJ et al (1988) Pattern of epithelial cell proliferation in colorectal mucosa of normal subjects and of patients with adenomatous polyps or cancer of the large bowel. Cancer Res 48:4121-4126

52. Terpstra OT, van Blankenstein M, Dees J, Eilers GA (1987) Abnormal pattern of cell proliferation in the entire colonic mucosa of patients with colon adenoma or cancer. Gastroenterology 92:704-708

53. Mills SJ, Mathers JC, Chapman PD, Burn J, Gunn A (2001) Colonic crypt cell proliferation state assessed by whole crypt microdissection in sporadic neoplasia and familial adenomatous polyposis. Gut 48:41-46

54. Santucci R, Volpe L, Zannoni U, Paganelli GM, Poggi B, Calabrese C, Biasco G (1997) Cell proliferation of the duodenal mucosa in patients affected by familial adenomatous polyposis. Gastroenterology 113:1159-1162

55. Lipkin M, Bell B, Sherlock P (1963) Proliferation kinetics in the gastrointestinal tract of man. Cell renewal in colon and rectum. J Clin Invest 42:767-776

56. Welters CF, Heineman E, Thunnissen FB, van den Bogaard AE, Soeters PB, Baeten CG (2002) Effect of dietary inulin supplementation on inflammation of pouch mucosa in patients with an ileal pouch-anal anastomosis. Dis Colon Rectum 45:621-627

57. Duffy M, O’Mahony L, Coffey JC, Collins JK, Shanahan F, Redmond HP, Kirwan WO (2002) Sulfate-reducing bacteria colonize pouches formed for ulcerative colitis but not for familial adenomatous polyposis. Dis Colon Rectum 45:384-388

58. Kolida S, Meyer D, Gibson GR (2007) A double-blind placebocontrolled study to establish the bifidogenic dose of inulin in healthy humans. Eur J Clin Nutr 61:1189-1195 